\title{
COMMUNICATION STRATEGIES USED BY THE PRIMARY TEACHERS IN EFL CLASSROOM
}

\author{
Ayu Oktaviani ${ }^{1}$ \\ STKIP PGRI LUBUKLINGGAU \\ Dwi Misgiyati ${ }^{2}$ \\ STKIP PGRI LUBUKLINGGAU \\ $\underline{\text { ayuoktaviani08@gmail.com }}{ }^{1}$
}

Submit, 24-10-2018 Accepted, 21-12-2018 Publish, 21-12-2018

\begin{abstract}
The objective of the research was to find out communication strategies used by the Primary teachers in EFL classroom. The sample of the research was 3 teachers in grade 2, 5 and 6 at Palm Kids Elementary School of Lubuklinggau. The samples were taken through Purposive sampling. The researcher used descriptive qualitative research and the data were collected by using observation, interview, and documentation(field note and video recording). The result revealed that communiction strategies used by the English teachers' were code switching, intralingual, IL based strategies, non-linguistics, cooperative, and formal reduction. In the other English teachers' responded towards are the communication strategies helped the students understood the meaning, made the students easier to understood the material, helped students to understand what English said, helped to explain the material more detail in teaching and learning process and made the students have to master English well.
\end{abstract}

Keyword: primary teachers, communication strategies, primary School

\section{INTRODUCTION}

In Indonesia, English for young learners (EYL) has been considered as foreign language where English is taught as a school subject that makes it difficult for the learners to have access to spoken English outside the classroom (Sutopo\& Mahardika, 2016:216). English at Elementary School is not the compulsory subject. It is the local content subject (Musthafa, 2010:120). English at elementary school as the local content subject is promoted by the policy of Ministry of Education and Culture Number 0487/4/1992, which states that schools can add the basic subjects in the curriculum, as long as the lesson is not contrary to the national education goals. Then, the policy has been followed by the Decree of the Ministry of Education and Culture Number 060/U/1993 dated February 25, 1993 about the possibility of the English program as a local content in elementary school that can be started in the $4^{\text {th }}$ grade. 
Decentralization of education in Indonesia has encouraged the local governments to make their own decisions relative to some portion of curricular space in the use of some learning hours that has become known as "local content" (Musthafa 2010:120). As result desentralized decision-making, since last decade, public interest in English for Young Learners (EFL) has become enhanced.

According to Suyanto(2008:15), Indonesian young learners are elementary schools students between 6 to 12 years old children. They are divided into two groups, younger group (6 to 8 years old) and older group (9 to 12 years old). Whereas, based on level, they are called Lower Classes, the students of grade 1, 2 and 3 and Upper Classes, the students of grade 4, 5 and 6.

Actually, the Indonesian government has realized that English is important for the country's development, especially in the effort of human resource development. Therefore, as a policy, the government has published Law Regulation No. 20 in 2003 about National Education System and Government Regulation No. 19 in 2005 about Standard of National Education. These policies are used as the guideline for all education components in conducting the Indonesian education system.

Similar to Lubuklinggau, English is not a majority language and students learned English as additional language or target language. In this side, the researcher has opinion that English is important to learn as target language in Lubuklinggau because English is needed to be learned as supporting subject for the students to develop their creativity, especially in language learning in Elementary School and to face brighter future. Therefore, English for young learner are the students of elementary school who learn English as additional subject. Especially for the younger because by learning the foreign language from the early age, the language will be more easily learned (Oktaviani\& Fauzan, 2017:4).

English is thecommunication tool in international situation. And then English is a global language is an unavoidable occurrence due to the efficient and effective communication demand and human being, especially when teaching English for young learners.

Teaching English to children (young learners) suggests, age plays a crucial role in what we teach and how we teach it. Since a young learners class is different from an adult or teenager class in term of the learners' language learning needs, the language competences emphasized, and the cognitive skills addressed. It is highly important to show the differences of these three learner groups keeping in mind the fact that every learner is unique and such lists can only reflect generalizations (Harmer,2007:82-83). In conclusion, teaching English to kids is not easy because they are still beginners. Before teaching, teacher should know about the characteristics of young learners. The characteristics of young learners 
(kids), such as 1) Students easily ask to change the material, 2) Students are interesting by using media to catch their intention, 3) Students need teacher everytime to ask everything. In additional, teachers should have communication strategy to communicate with the young learners, in order the young learners can study the language skills.

According to Faerch and Kasper cited in Cervantes \& Rodriguez (2012:114) that Communication strategies (CSs) is who emphasized the planning and execution of speech production. Besides, communication is the ability to share information with people and to understand what information and feelings are being conveyed by others.

Actually, the importance of communication strategies in the research: First, communication strategy training may promote learners' awareness to use their linguistic resources to minimize communication problem. Second, strategic competence is a part of learners' communicative competence. Third, communication strategy training bridges the gap between classroom and real-life communication. Finally, communication strategy training contributes to the students' security, self-confidence, and motivation to communicate. The result of the interview with one of English teacher at Palm Kids Schoolon April, 2018. First, teaching English in primary school is important because English is everywhere. English is not only in the class but also English is in students' daily life. Second, teacher's explanation in teacher experience when the teachers taught the students by using two languages in classroom, the teachers used second language (L2) and target language (TL). Third, there are communication strategy used by the teachers to communicate with students in class such as code mixing, switching, gesture etc. In conclusion, the teacher needs communication strategy in class in order to make easy the students to understand the material. In short, commmunication strategies are important to analyze because the teacher can teach easier and students more understand the material. Based on explain above, English is interesting to learn. Based on the reasons above, the researcher is chosen this research at Palm Kids School, because Palm kids school is a characterbased Global school and the students have good basic in English through they still young children and students' ability in speech is good. and based on the interview result with the teacher the English teachers used several CSs in teaching.

\section{LITERATURE REVIEW}

In education life, level of education or system is various in each countries. In Republic of Belarus, prime education is provided in primary schools and in grades 1-4 of secondary schools and gymnasiums. Developing character's children is easier seen in primary school level. 
According to Tinsley \& Comfort (2012:39), at the primary level the English subject curriculum is characterized by practical and aesthetic terms indicating that the pupils are meant to participate in English children's culture and literature through words, pictures, music and movement. The subject curriculum also stresses awareness of the similarities between English, the mother tongue and other language, the structure of the language,text composition and use of digital media in language teaching.

In our country, there are 6 level to finish the primary school. They are, $1^{\text {st }}$ grade until $6^{\text {th }}$ grade. The students in primary schoolare known as young learners. According to Suyanto(2008:15), Indonesian young learners are elementary schools students between 6 to 12 years old children. They are divided into two groups, young group (6 to 8 years old) and old group (9 to 12 years old). In level side, they are called Lower class (1,2, and 3 grade) and Upper class (4,5, and 6 grade).

Communication or communicative is language form and knowledge that anable a person to communicate functionally and interactively (Brown, 1941:196). While strategies of communication are related to strategies of learning, it is nevertheless appropriate to consider the two types separately, receptive, and productive competency. So, Communication is the ability to share information with people and to understand what information and feelings are being conveyed by others. Then, Communication can take on many forms including gestures, facial expressions, signs, vocalizations (including pitch and tone), in addition to speech and written communication.

In this research, one indication that a teacher is frequently asking questions than students. So that, the students can answer the questions in many times this activities like teacher center.

Communication strategies are provides an overview of the teachability issue, discussing the arguments for and againts strategy instruction, and suggest three possible reasons for the existing controversy (Donyei, 1995:55). When attempting to communicate a message to listeners, a speaker may have to struggle to find appropriate and grammatical constructions to compensate for gaps between what he or she intends to express and the available linguistic resources. According to Faerch and Kasper (1980:39) explains that distinction between two major types categoriesof communication in terms of reduction strategies and achievement strategies. The learners' attempt to avoid the problem being a reduction strategy and his attempt to achieve of solution being an achievement strategy.

In teaching, teachers need to attract the students to follow the lesson. Young learners are easy to got bored. Teachers have to stimulate them in giving question or get to communicate with the students. The using of communication strategy make students close with the material and know the instruction that 
happen in class activities. Communication with students in teaching learning activity is one activity that will make succeed of teaching activities, because the teachers give the clues, introduction, brainstorming and elaboration.

According to Faerch and Kasper (1980:38) explains that communication strategies divided into two types: achievement and reduction strategies. The two types are supported each other and it are follows: (1) code switching, (2) interlingual transfer, (3) IL based strategies, (4) cooperative strategies, (5) nonverbal strategies, (6) formal reduction strategies, (7) functional reduction strategies. Achievement strategies allow learners to have an alternative plan to achieve teaching an original goal using the resources to have an alternative that are available. And reduction strategies play an important role in learners' process of second language acquisition. Thetypes of communication strategies are follow:

\section{Code-switching}

In communication in which foreign languages are involved, there always exists the possibility of switching from L2 to either L1 and another foreign language. The extent to which the switching happens depends on the interactanalysis of the real communicative situation (Færch and Kasper 1980:48). For example, foreign classroom students often share the L1 with their teacher, which enables them to switch code extensively between L2 and L1.

\section{Inter-lingual Transfer}

Learners always ignore the IL code when using the code-switching strategy. However, strategies of inter-lingual transfer result in a combination of linguistic features from the IL and L1. Inter-lingual transfer may not only occur on the phonological level but also at the pragmatic level (Færch\& Kasper 1980:48). For example:

(a) Native speaker: How do you read the word "think"?

(b) Learner: Um, /sik/

(in Chinese there is no $/ \theta /$ for $/ \mathrm{th} /$, there is only $/ \mathrm{s} /$ similar to $/ \theta /$ in English)

(c) Learner: Sorry, it's my secret.

(Chinese learners of English often use "where are you going?" "Did

You have your supper?" etc. for greeting).

\section{IL Based Strategies}

By using their IL (Inter Language) system, learners may have several ways of coping with communicative problems, such as generalize, paraphrase, coin new words or restructure. From the perspective of IL, generalization means that learners solve problems in the planning phase by filling "gaps" in their plans with IL items which they would not normally use in such context. While, from the 
perspective of L2, the strategy resembles over generalization of an L2 item, as it results in the extension of an item to an inappropriate context. For example, we often use the word fruit to stand for a particular type of fruit, tangerine. Paraphrase strategy means the learner replaces an L2 item by describing or exemplifying it. Paraphrase refers to not only the form of description or circumlocutions but also bears the form of exemplification.

For instance:

"Lily: ...Um, something that you use when your hair is wet and you want to dry it...

Marry: Oh, you mean hair dryer."

"Jack: ...You take it when you want to make tea or coffee.

Jim: Um, that's kettle".

Word coinage refers to the strategy that the learner replaces an L2 item with a new created L2 item. In the following example the learner wants to talk about "the curve of stadium". E.g. we were sitting in the rounding of the stadium and ... Restructuring strategy is used whenever the learner realizes that he cannot finish her previous plan, and develops an alternative constituent plan to ensure the expressing of her message. E.g. I must eat something

(the learner wants to exprese that he is hungry).

\section{Cooperative Strategies}

Færch and Kasper (1980:52) explain "although problems in interaction are necessarily shared problems and can be solved by joint efforts, they originate in either of the interactions, and it is up to her (the speaker) to decide whether to attempt a solution herself or to signal her problems to her interlocutor and attempt to get the problem solved on a cooperative basis". If the individual decides to resort to his interlocutor that he is experiencing a communicative problem and that she needs help, he makes use of the cooperative communication strategy of "appealing". Appeals can be characterized as "self-initiated other-repairs". As can be seen in the following example: Student: Miss, how do you spell "star"? Teacher: S-t (and then look at car referring to the word "car".

\section{Non-linguistic Strategy}

Non-linguistic strategy means the strategy which learners use to replace a lexical item or an action. In our daily communications, individuals often use nonlingusitic strategies, such as mime, gesture and sound-imitation. Although nonlinguistic strategies are sometimes use the learner's one and only attempt at solving a communicative problem less they are often used to "support". it isvery important to signal an appeal to the interlocutor. Furthermore, non-linguistic including not only the gestures, posture, facial expression but also other signs 
which are possible to present by a communicator, for instance, his address or his hair style (Færch and Kasper 1980:34).

\section{Formal Reduction Strategies}

All areas of the IL system are susceptible to formal reduction. However, because of different communicative status of items from different linguistics levels there are some significant differences with respect to what subsequent strategies are needed in the case od reduction at the phonological, the morphological, the syntactic and the lexical level. Most items at the phonological level highly obligatory in all communicative situations. Thus it is no adoubt the exception rather than the rule, that a particular phoneme is restricted to specific words. The formal reduction strategies refer to the reduction by which parts oflinguistic system are avoided. Learners tend to adopt formal reduction strategies mainly for the following two reasons.

As at the phonological level, some items are indispensable in communication, learners cannot simply communicate by a reduced phonological system. What is more, some particular phonemes are restricted to specific words which can still not use a reduced phonological system, such as topic avoidance. The case at the morphological level is similar to that at the phonological level. In most communicative situations, grammatical morphemes are generally in particular linguistic contexts. That is to say, in the case of morphological reduction, an item has often to be compensated by the application of various achievement strategies, normally by replacing the avoided morphological item with syntactic or lexical items. Nevertheless, even if grammatical morphemes are normally indispensable components of a sentence, they are frequently semantically redundant. When in a real communicative case, learners may prevent from using some of these unnecessary features.

\section{Fuctional Reduction Strategies}

Færch and Kasper (1980:45) point out that functional reduction may affect the following threemain types of elements of the communicative goal: actionable communicative goal, modalcommunicative goal and propositional communicative goal.Functional reduction of the actionable communicative goal may be reduced when learnersexperience difficulties in performing specific speech acts. Functional reduction of modalcommunicative goal may occur to the learners who experience problems in making theirutterance appropriate for politeness or social distance. When coming across communicativetasks which demand other types of speech acts (for example, argumentative directivefunctions), learners may experience considerable problems in performing tense.Functional reduction of the propositional content includes strategies such as topic avoidance, message 
abandonment, and meaning replacement. By using topic avoidance is meant that learners manage to prevent the occurrence of topics that are certain to present difficulties. Topic avoidance refers to the strategy of avoiding formulating goals which include topics that are perceived as problematic from a linguistic point of view. Message abandonment which can also be used in connection with a retrieval problem in the realization phase. Message abandonment is communication on a topic is initiated but then cut short because the learner runs into difficulty with a target language form or rule.

The result of topic avoidance and message abandonment is that the learner gives up referring to a specific topic. While, meaning replacement is different. Færch and Kasper (1980:46) describe meaning replacement in the following way: confronted by a planning or retrieval problem, learners operate within the intended propositional content and preserve the topic butrefer to it by a more general expression. The result of meaning replacement is a certain amount of vagueness.

The distinction between "topic avoidance" and "meaning replacement" is as arbitrary as the distinction between what constitude concepts belonging to one and the same topic and concepts belonging to different topics. Rather than visualize the propositional reduction strategies (apart from message abandonment) as falling neatly into one of two classes, one should see them as forming a countinue. At the one end, the learners says "almost" what she wants to say about a given topic (meaning replacement), at the other end she says nothing at all about this (topic avoidance).

From the explanation above, the researcher identified English teachers' about communication strategies that used when teaching and learning process in the classroom with the students.

\section{RESEARCH METHOD}

The researcher was used descriptive qualitative research in conducting the research. According to Latief(2014:75), qualitative research is a process of inquire aimed at understanding human behavior by building complex, holistic pictures of the social and cultural settings in which such behavior occurs.

According to Fraenkel\&Wallen (2009:422), qualitative research is research studies that investigate the quality of relationship, activities, situations or materials.In this research, the researcher was used descriptive qualitative research because this research was not collecting the numerical data. The data is collected in the form of words and data collected were the subject's experience to communicate when in teaching learning in classrom. The researcher only discussed and analyzed English Teachers' communication strategies of Palm Kids 
School. The researcher collected the information several time, although the time it was be took to collect all of the data may take in classroom.

The researcher submitted the information just at one point in time, although when collect all of the data from different place and time, such as one day, several weeks, several months and years.

The subject in this research is the English teachers of Palm Kids School. Subject is the person, place, thing or idea that is doing or being something (Frankel \& Wallen, 2009:299). Indonesian young learners are elementary schools students between 6 to 12 years old children. They are divided into two groups, younger group (6 to 8 years old) and older group (9 to 12 years old). So, This research will use the subject are Lower Classes and Upper Classes English teachers. Lower classes are the students of grade 1, 2, and 3 and Upper classes, the students of grade 4, 5, and 6 at primary school of Palm Kids School. In this research, the subject was all the English teachers from grade 1 until 6 in Palm Kids School.

In this research, the researcher used non probability as the technique of sampling. In this research, the researcher used non probability as the technique of sampling.According to Sugiyono (2010:141-142), nonprobability sampling is the technique of sampling that do not provide equal or opportunities for each elements of the population to select a sample. This technique of sampling through systematic sampling, quota sampling, insidental sampling, purposive sampling, saturate sampling and snowball sampling.

The reseacher used purposive sampling as technique sampling. Because of the depth and extent of the information sought in qualitative studies, purposive sampling are typically small.

Fraenkel \& Wallen (2009:99), stated that purposive samplingis different form convenience sampling in that researchers do not simply study whoever is available but rather use their judgment to select a sample that they believe, based on prior information, will provide the data they need. In addition, (Sugiyono, 2010:144) state that, purposive sampling is technique sampling of source the data with certain considerations.

Based on the technique of sampling above, from the subject there were 6 English teachers. They were grade 1 until 6 . The researcher took three (3) teachers as the subject because the researcher was selected based on their educational background. Based on six (6) teachers, only three (3) teachers to grade 2, 5, and 6 who have Bachelor's Degree of English Education background. And three (3) from six English teachers who have not English education but agricultural, math and Indonesia education. In conclusion, purposive sampling used in this research was based on researcher's need. 
In this research, the researcher collected the data by using triagulation method. Triagulation method means different instruments to get the same data at the same times (Sugiyono, 2010:241). The researcher used observation, interview, and documentation (field note and video recording) at the same time.

\section{Observation}

Observation is an observation which is focus on the understanding of how social interaction events in the classroom. Observation applied to monitor the teacher and the students' activities during teaching and learning process. The researcher took notes focusing on the teacher behavior is the process relate to instruction and students responses.

According to Latief (2014:149), stated that observing is the process of collecting data indicating the success of the strategy in solving the classroom problems. According to Ary et al. (2002:432), there are two types of observation; participant and non participant observation.

In this research, The researcher used non participant observation to get the data because the researcher does not take any active part in classroom activities (Ary et al. 2002:432). The researcher sits in class to observe the classroom activities. And also the researcher observed communicate English teachers by using observation sheet.Then, the researcher checked the activity of the teacher in the classroom.

\section{Interview}

According to Frankel \& Wallen (2009:445), interview is an important way for a researcher to check the accuracy of to verify or refute the impressions he or she has gained through observation. In addition, According to Sugiyono (2010:138-140) state that, interview is used as data collection technique if the researcher want to do a preliminary study to find out the problem to be researcher. There are two types of interview; structured and un-structured interview. In this research, the researcher used un-structured interview. it is opened interview, where the researcher does not use systematically interview guideline in collecting the information. Therefore, in this research, the researcher was prepared the interview sheet in form of 13 written questions. All interview was started with short introduction from English Teachers. Then, it be continued the English teacher were thought and developed their answer on the questions gave based on communication strategies used.

\section{Documentation (Field Note and Video Recording)}

According to Sugiyono (2010:240) documentation is daily field note in form text, picture, sketch, video and many others. In addition, According to Ary et al. (2002:435) field note is the common method of recording the data collected 
during observation. The researcher might made brief notes during the observation but then later expands his or her accounted of the observation as field note. Notes may sepplement information from other source, including documents and interviews, or they might comprised the main research data. If no computer is available within a day, you should expand your notes by hand.

In this research also, the researcher was recorded every situation in the classroom activities used by video recorder. Then, the researcher was written or analyzed result from observation sheet and video record the activity of the teacher in the classroom from pre-task, whilst-task and post-task. In this research, the researcher as non participant was recorded and observed at the same time. And based on the data of observation and documentation, the reseacher has interview the English teachers or subject.

To analyze the research data,the researcher was analyzed the data.There were several steps and procedures that used by the researcher, they were as follows: Identification, In this step, the researcher was identified thecommunication strategies thatused by the English Teachers'. Then, the researcher was identified the data transcription in the video recording about teaching techniques and it was implementation in classroom activities. And cross checking the recording data with the observation checklist and the result of interview.

Classification, In this step, the researcher was classified the result of observation, interview and documentation (field note) into two categories; teaching techniques and the implementation of techniques. Then, classifying the result observation, interview and documentation by confirming the communication strategies that used by the English Teachers. The types of communication strategies were achievement and reduction strategies. Achievement strategies were included code-switching, inter-lingual transfer, IL based strategies, cooperative strategies, and non-linguistic strategies. Reduction strategies include formal reduction strategies and functional reduction strategies.

Description, In this research, the researcherdescribed the data in the form of table which consist of analysis communication strategies thatused by the English teachers. Conclusion, Finally, the researcherconcluded the result of the research after analyzed the data. The researchersummarized the communication strategies thatused by English teacherson teaching learning process. Accountability of the Research, there were: Credibility is confidence in the "truth" of the finding (Lincoln and Guba cited in Jhonson, 2016:1). In this research, the researcher analyzed the communication strategies by used English teachers of Palm Kids School for several times and also collected some references to support this research. 
TransferabilityLincoln and Guba cited in Jhonson (2016:1) state that transferability refers to showing that the findings have applicablity in other contexts. To make the result of this research understood by all English teachers, this research gave a detail information to other researcher in conducting a similiar topic and the other researcher would got some knowledge about communication strategies which English teachers often used in their communication with student in teaching learning activities in classroom.

Dependability refers to showing that the findings are consistent and could be repeated (Lincoln and Guba cited in Jhonson, 2016:1). To make the data of this research consistended, the researcher used observation, interview and took documentation in communucation strategies used by English teachers of Palm Kids School at the same time. Then, the researcher analyzed the data more than one time.

Confirmability is a degree of neutraility or the extent to which the findings of a study are shaped by the respondents and not researcher bias, motivation, or interest (Lincoln and Guba cited in Jhonson, 2016:1). To make the data of this reserach, the researcher checked the result data of the research with instruments that have been preapared. And then, this research can be documented.

\section{FINDING}

The findings of the reserach. Based on the formulation of the problems, the researcher found out English teachers' communication strategies in EFL classroom. This research was taken from observation, interview and documentation (field note and video recording) in Palm Kids School. Observation is the process of collecting data indicating the success of the strategy in solving the classroom problemss (Latief, 2014:149). Meanwhile, Based on Frankel \& Wallen (2009:445), interview is an important way for a researcher to check the accuracy of to verify or refute the impressions he or she has gained through observation. Then, documentation is daily field note in form text, picture, sketch, video and many others (Sugiyono, 2010:240).

The observation in this research, researcher sat in class to observe the classroom activities. And also the researcher observed communicate English teachers used by observation sheet of the instrument. The researcher checked the activity of the teacher in the classroom. Therefore, interview contained 13 unstructured questions related to the indicators of the instrument. All interviews was started with an introduction from the respondents, it could be seen to answer the questions that was given by the researcher. The documentation, the researcher was recorded every situation in the classroom activities by using video recorder. The researcher could be written or analyzed result from observation sheet and video record English teachers activities in the classroom from pre-task, whilst-task and 
post-task. In this research, the researcher was non-participant which recorded and observed at the same time.

Based on the instruments above, the researcher found out communication strategies used by the English teachers. The following table were showed the result of observation, interview and documentation (field note and video recording).

\section{Communication Strategies Used by the English Teachers of Palm Kids School.}

1. Code Switching

$\mathrm{X}$ : Sssttt.. role number two, tree lihat ini tree if more than one that gues or not

$\mathrm{S}$ : There are, X:Pencil, eraser, there are many things, right?(Grade 2)

$\mathrm{Z}$ : When the something happened it is means that ketika gempa terjadi saya sedang that is combination(Grade 5)

$\mathrm{X}$ : For about kira-kira selama 9 tahun read the next sentence, next sentence since again to don't speak. (Grade 6)

2. Inter-lingual Strategies

X:Class... no stop. Nah... miss Ely say to miss Weni yes, to play paper. The paper in the book just youwrite important thing not playing. (Grade 2)

Z: I think speaker can full and imposible because the music et et.

(Grade 5)

$\mathrm{X}$ : Miss Ely give the star today

S : Itu...

$\mathrm{X}$ : Devis, please playing the star, right?

S : Gak ada(Grade6)

3. IL Based Strategies

$\mathrm{X}$ : So, you have to draw . Draw up to you, how many things, just ine is okay. But you use there is, there more than one it's okay, you use there are. Draw the picture (Grade2)

$\mathrm{Z}$ : Okay, before we start our lesson. Please, I write down scores. What you learn yesterday, what were you learn yesterday. Alfa, Nadia. Alfa present?(Grade 5)

4. Non-linguistics Strategies

$\mathrm{X}$ : There are...

Because, there are fivepencils. It means more than one(Grade 2)

$\mathrm{Z}$ : I need you thinkone sentence. Eeee... twelve students, twelve..twelve

S : Our baby sitter(Grade 5)

$\mathrm{X}$ : You prepare one word in your book since pag, start from page to vocabulary for. Four until twelve. You may choose one word

(Grade 6)

5. Cooperative Strategies

$\mathrm{X}$ : Sarapan Pagi, brush your teeth, kelvin

S: Gosok gigi

X: Role number two, gosok gigi. Go to school? Clara

S: Balik ke sekolah(Grade 2)

$\mathrm{Z}$ : Are you camp in the... 
S : Sky

Z : There was...

S : Fire(Grade5)

$\mathrm{X}$ : You prepare one word in your book since pag, start from page to vocabulary for.

Four until twelve. You may choose one word(Grade 6)

6. Formal Reduction Strategies

$\mathrm{X}$ : Looked page nine, okay class...

$\mathrm{S}:$ Yes

$\mathrm{X}$ :Class...class...class

S : Yes...yes...yes(Grade 2)

$\mathrm{Z}$ : Okay, no there is not

Open your book please, were your book pages ten

$\mathrm{S}$ : Miss eleven or ten(Grade 5)

$\mathrm{X}$ : Player statement is pasangan, that I mean wait statement for.

Class...

S : Yes(Grade 6)

\section{DISCUSSION}

\section{Code Switching}

Based on the observation, interview and documentation, the researcher found out three (3) teachers used code switching strategies when communicate was taught in teaching and learning process in the classroom. Accoding to Faerch kasper (1980:48), in communication in which foreign languages are involved, there always exists the possibility of switching from L2 to either L1 and another foreign language. When the researcher took observation, interview and documentation was seen between the teacher and students good interaction, the students to make easy to be understand well about discussion, the material and more focus on the learning process in classroom.

This strategy has appropriated to apply in teaching and learning process because code switching helped the students in learning English because the students were to know the meaning about of the English teacher said. Based in the interview, code switching was used by the English teacher in the low level grade 1(one) until three (3).Furthermore, code switching was used by the English teachers to help the students if they were felt to confuse. In the class, the teachers switch and made the students more able to increase vocabulary mastery. From the conversation show that, the English teachers use it, when English teachers wanted to explain the meaning of her said. Hoped the students to understood the material. The English teachers switched in L1 to either L2 which enables her to code switch extensively between L2 and L1.

\section{Inter-lingual Transfer}

According to Faerch \& Kasper (1980:48), inter-lingual transfer may not only occur on the phonological level but also at the pragmatic level. The teaches 
used interlingual transfer strategy taught communicate with students. Based on the interview all of the teachers used this strategy. The teachers could helped students to understand what were English teachers said and helped English teachers if they to forget word when giving time to teach in the classroom.

These dialogues from examples, the use of "nah" whereas with the code switching strategy, the English teacher ignore the IL code in a combination of linguistic features from the IL and L1. Furthermore, the use of "the music et $\boldsymbol{e}$ "thattheEnglish teacher used it, because she showed to expression to the students with L1. It means that she given kidding to the students. Then, that continued of the conversation of English teacher and student about the star. The English teacher uses it when she said the star, it means that the star is score for active students.

\section{IL Based Strategies}

The researcher took interview in the office teacher. The researcher found out two (2) English teachers were used it. Based on Faerch \& Kasper (1980:49), that IL based strategies devide four items, they are generalization, paraphrase, word coinage and restructuring. Generalization is learners solve problems in the olanning phase by filling"gaps" in their plans with IL items which they would not normally use in such context. Pharaphrase means that the learner replace an L2 item by describing or exemplifying. Word coinage refers to the strategy that the learner replaces an L2 item with a new created L2 item. Restructuring is used whenever the learner realizes that she cannot finish her previous plan and develops an alternative cinstituent plan to ensure the expressing of her message.

The result were showed that the students could got meaning word could understood what was English teachers mean in instruction or the material and the English teachers could helped to explain the material more detail for the students in teaching and learning process.From the dialogues above, the English teacher was used IL based strategies when they said draw "the pictures" and scores. The words the pictures and core is generalization.Generalization is learners solve problems in the planning phase by filling "gaps" in their plans with IL items which they would not normally use in such context. Example in which the English teacher uses the superordinate term "The picture" is refers to photo, animal, etc and score is refers to 70,80 or 100 .

\section{Cooperative Strategies}

The researcher took the instruments, the researcher found out there were all of English teachers used cooperative strategies in teaching and learning in the classroom. Based on the observation, the researcher was seen the students participated on this activities because this strategy made the students were able to 
work together and this strategy could helped the students active in teaching learning activities and made the students exchange in their mind.

Furthermore, this strategy was used by the English teachers because the teachers given action for soft problems, the students could felt easier because the students could also seat knowledge to need other and discussed the problems soft together. In the Palm Sids school, English teachers used the approach if in ABL (Acquire Based Learning) in learning process to teach the students. According to Faerch \& Kasper (1980:52), that although problems in interaction are necessarily shared problems and can be solved by joint efforts.

From the dialogues above, the English teacher used cooperative strategies in this discussion. It showed that this strategy when English teacher needed responses from the students and expression signaling direct appeal such as "what's difference since and for?", “There was...", “Go to school?". A questions was used as a clue of cooperative strategy for assistance to the students.

\section{Non-linguistics Strategies}

According to Faerch \& Kasper (1980:53), that in face to face communication, resort to non-linguistics strategies such as mime, gesture, and sound imitation. Then, based on the instruments of the research, the researcher got there were English teacher used non-linguistics strategies like mime and gesture in teaching learning in the classroom when the teachers expalined the material. From the observation and documentation, the teachers used mime and gesture helped the students comprehended what the teacher explain.

This strategy has benefits for the teachers and students. For the teachers, easy to explain with gesture and receive directly by the students actually when taught vocabulary. For the students, more understood the meaning of English teachers said in front of class. In conclusion, this strategies helped the students in communicating and understanding the lesson.

The English teacher was used non-linguistics strategies in this discussion. The use "one" and "five" it showed that English teacher by using gesture in her finger to show the students. The English teacher used her finger to support the students in understanding what was structured. Then, the use "think"itshowed that English teacher by using gesture in hold head to support delivering messages to the English teacher.

\section{Formal Reduction Strategies}

Based on the instruments, there were all of teachers used formal reduction strategies in teaching and learning process. Furthermore, the English teacher sometimes if the students do not understand about English teacher said. They helped to use formal reduction strategies search the other lexical of the words, 
made the students to easier to understand the material. If the students got to confuse of the lesson, so they could give action to be in correct or false. Meanwhile, based on Faerch \&Kasper (1980:40), the formal reduction strategies to avoid producing non-fluent or incorrect untterances by realizing insufficiently automatized or hypothetical rules.

The English teacher was used formal reduction strategies in this utterences. The use "page nine", "were your book". Its was morphological. Morphological is at least as seen from a superficial point of view, similar to that at the phonological level, grammatical morphems are normally obligatory in particular linguistics contexts and these context are used in most communication situations. These conversation show that English teacher talks to the students about looked page nine. It's meant that incorrect, because page nine more than one page. So, the correct was pages nine. And then were your book also incorrect because when English teacher talks open your book please, were your book pages ten and that was not use tobe. The correct was "open your book please, your book pages ten". The conversation English teacher grade 6 was player statement is pasangan. Itmeant that English teacher forgot used Target language, so she was using indonesia language.

\section{CONCLUSION}

From the findings of the research that have been found and discussed in Chapter IV, the reseracher can conclude that two English teachers in Three (3) classes of Palm Kids School used five strategies in learning process in the classroom activities, they were code switching strategies, inter-lingual strategies, IL based strategies, non-linguistics strategies, cooperative strategies, and formal reduction strategies. Based on the results of the instruments, the researcher found that the used of Communication Strategies (CSs) can help the students more understand in learning English especially in the classroom activities.From the result of the instruments (observation, instrument and documentation), that are the answered by respondents in the observation, interview and documentation, the researcher found out several reasons why Communication strategies (CSs) should be used by in English Teachers in EFL classroom for Primary School. The Teachers of Palm Kids School assumed that the Communication Strategies (CSs) should be used by English teachers because of several reasons. The first, make the students learn English easily, the second, help the students understand the meaning, the third, helpremind the students about the material, The fourth, stimulus the student can understand and be active in the class, and the last, the students can speak English well. 


\section{REFERENCES}

Ary, D. J., Lucy, C \&Razavieh, A. (2002). Introduction to Research in Education. $\left(8^{\text {th }}\right.$ Ed.).Belmot: Wardsworld, Thomson Learning.

Brown, H. D. (1941). Principles of Language Learning and Teaching. New York:University of LLLinois.

Cervantez, C. A. \& Rodriguez, R. R. (2012). The Use Communication Strategies in the Beginner EFL Classroom. (vol_6):Universidad Autonoma de Tamaulipas, Mexico. Pp.111-128.

Donyei, Z. (1995). On the teachability of Communication Strategies. TESOL Quartely (29,55-58)

Harmer, J. (2007). The Practice of English Language Teaching (4 ${ }^{\text {th }}$ Ed.).. Cambridge: Pearson Longman.

Faerch, C. \& Kaper, G. (1980). Processes and Strategies in Foreign Language Learning and Communication. Interlanguage studies Bulletin utrecht (pp, 1-73). Netherlands.

Fraenkel, J.R. \&Wallen, N.E. (2009). How to Design and Evaluate Research inEducation ( $7^{\text {th }}$ Ed.). New York: McGraw-Hill Companies.

Latief, M. A. (2014). Research Methods on Language Learning: An Introduction.

Malang: UniversitasNegeri Malang.

Jhonson, S. (2016). Qualitative Impact Evaluation: Incoporating Autenticity into The Asessment of Rigour:University of Bath

Musthafa, B. (2010). Teaching English to Young Learners in Indonesia: EssentialRequirements.Depok: Indonesia University of Education. Retrievedfromhttp://file.upi.edu/Direktori/JURNAL/EDUCATIONIST/Vo 1._IV_No._2-Juli_2010/07_Bachrudin_Musthafa.pdf

Oktaviani, A., \& Fauzan, A. (2017). Teachers Perceptions about the Importance of English for Young Learners. Linguistic, English Education and Art (LEEA) Journal, 1(1), 1-15. https://doi.org/https://doi.org/10.31539/leea.v1i1.25

Sugiyono. (2010).MetodePenelitianKuantitatif, Kualitatifdan R\&D. Bandung: Alfabeta Bandung.

(2015). Metode Penelitian \& Pengembangan R\&D. Bandung: Alfabeta Bandung. Sutopo, \&Marhadika., (2016). The Use of Communication Strategies Among Indonesian Young Learners of English in Early Total Immersion Program (Vol_7):University SekaranGunungPatiSemarang. Retrieved.fromhttps://www.shs.conferences.org/articles/shsconf/pdf/2016/ 04/shsconf_erpa2016_01001.pdf

Suyanto, K.E. (2008). English for Young Learners. Jakarta: PT BumiAksara.

Tinsley, T. \& Comfort, T. (2012).Lesson from Abroad: International Review of Primary Languages. London:CFBT Education Trust.

Undang-undangtentangSistemPendidikanNasional.Retrieved November $15^{\text {th, }}$ 2016,fromhttp://pustakamateri.web.id/undang-undang-tentang-sistempendidikan-nasional/. 